\title{
KOLABORASI ILUSTRASI DAN TEMBANG DOLANAN DALAM PENCIPTAAN MEDIA EDUKASI COVID-19 DI SURAKARTA
}

\author{
Basnendar Herry Prilosadoso ${ }^{1)}$, Waluyo ${ }^{2)}$, Roman Aqviriyoso ${ }^{3)}$ \\ ${ }^{1}$ Fakultas Seni Rupa dan Desain, ISI Surakarta \\ email: basnendart@yahoo.com \\ ${ }^{2}$ Fakultas Seni Pertunjukan, ISI Surakarta \\ email:waluyo@isi-ska.ac.id \\ ${ }^{3}$ Fakultas Seni Rupa dan Desain, ISI Surakarta \\ email: romanavi@std.isi-ska.ac.id
}

\begin{abstract}
The Covid-19 outbreak has attacked the community, where the Indonesian Government has handled the pandemic outbreak from health, social, politicaDolanan Song, Illustration, Covid-19, Education, Elementary School Students.I, economic and other related aspects. Various educational media, information, and publications regarding the prevention and spread of this virus have also been carried out in multiple ways and with multiple media. Dissemination of information about the Corona outbreak is needed by all groups, from all age groups, economic status, gender, demographics and other aspects. Likewise, for elementary students, at that age, the information can be used as a guide later, both now and future. An appropriate media for segmentation is needed so that the information presented is acceptable and attractive. Alternative media for illustrated collaboration with tembang dolanan contain moral teachings and conveying media that can apply Dolanan Song, Illustration, Covid-19, Education, Elementary School Students.in preserving mother tongue and character education. The purpose of creating art is children's illustration work and dolanan songs containing interesting material and publication media regarding the prevention and spread of the Covid-19 virus to elementary school students. The method of creating artwork has 6 (six) stages, namely: Discovery, Interpretation, Ideation, Experimentation, Evolution, and Implementation. Through this media, it hoped that it could increase understanding and knowledge, especially elementary school students, in preventing and overcoming the Covid-19 outbreak so that the attack can soon subside.
\end{abstract}

Keywords: tembang dolanan, illustration, Covid-19, education, elementary school students.

\section{PENDAHULUAN}

Sekitar bulan Desember 2019 di Wuhan, Hubei, Cina banyak muncul kasus pneumonia yang belum diketahui asal penyebabnya, dengan gambaran klinis sangat mirip virus pneumonia. Hasil uji laboratorium dengan mengambil sampel saluran pernapasan menunjukkan adanya coronavirus baru, yang bernama novel coronavirus 2019 (2019-nCoV). Pada bulan Desember tersebut telah ditemukan yang dinyatakan terinfeksi lebih dari 800 kasus yang di dalamnya juga menerpa para pekerja layanan kesehatan yang teridentifikasi berada di Wuhan, dan beberapa kasus yang di provinsi lainnya di Cina, beberapa negara di Asia, seperti Thailand, Jepang, Korea Selatan, dan Amerika Serikat.
(Pramana, 2020). Penamaan sekumpulan virus dari subfamili Orthocronavirinae dalam keluarga Coronaviridae dan ordo Nidovirales ini, disebut Coronavirus. Paparan virus ini membawa penyakit pada burung, mamalia, dan manusia. Coronavirus ini menyerang pada manusia sehingga menyebabkan infeksi saluran pernapasan dengan gejala umum ringan, berupa pilek, meskipun beberapa bentuk penyakit seperti; SARS, MERS, dan Covid-19 sifatnya lebih berbahaya dan bisa berdampak fatal (Yunus \& Rezki, 2020).

Wabah pandemi yang menerpa masyarakat ini sebagai virus yang sangat berbahaya dan jangan dianggap masalah yang sepele. 
Terlihat dari gejalanya yang secara umum akan sebatas influenza biasa, tetapi bagi analisis kedokteran bahwasanya virus ini perlu penanganan serius. Perkembangan penularan virus pada tahun 2020 ini terlihat cukup signifikan dengan ditandai hampir sebagian wilayah di dunia merasakan dampaknya termasuk Indonesia. Tindakan mencegah dan menanggulangi penyebaran virus corona sudah dilakukan secara masif di seluruh wilayah di Indonesia. Salah satunya diantaranya dengan kebijakan membatasi aktifitas di luar rumah, kegiatan sekolah sementara dilakukan secara daring, bekerja dari rumah (work from home), bahkan kegiatan beribadahpun dianjurkan untuk dilakukan di rumah. Kebijakan yang dikeluarkan oleh pemerintah ini sudah didasarkan atas pertimbangan yang sudah dikaji dengan baik.

Masyarakat yang sudah terinfeksi Covid-19 sebagian besar akan mengalami seperti gejala pernafasan tahap ringan, sedang dan sampai sembuh tanpa memerlukan perawatan khusus. Sedangkan pada usia lanjut dan mereka yang mempunyai riwayat penyakit kardiovaskular, diabetes, penyakit pernapasan kronis, dan kanker lebih mungkin akan meningkatkan penyakit ke tingkat yang lebih serius (Wajdi et al., 2020).

Data terakhir yang diambil dari portal berita Kompas.Com dimana per tanggal 4 Nopember 2020, jumlah yang terdampak virus Covid-19 di Indonesia dapat dilihat dari informasi dibawah ini.

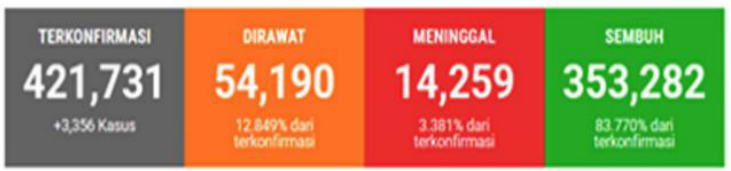

Gambar 1. Data Covid-19 di Indonesia per tanggal 4 Nopember 2020

Sumber : Kompas.com, 2020

Data tersebut memperlihatkan jumlah yang terdampak wabah pandemik ini masih dalam taraf mengkawatirkan, walau pemerintah sudah berupaya keras melalui beragam peraturan dan strategi untuk mencegah dan memutus penyebaran virus ini. Selain itu dalam grafik perkembangan Covid-19 yang terlihat kenaikan terkonfirmasi yang meningkat tajam, walau tingkat kesembuhan juga menaik grafiknya, selain itu grafik yang meninggal cenderung merata.

Antisipasi penyebaran virus tersebut, akhirnya pemerintah menyusun kebijakan, yaitu dengan membuat anjuran berupa pembatasan sosial (social distancing). Ini dilakukan dikarenakan bahwa penularan dari Covid-19 ini bersifat droplet, yaitu percikan lender berukuran kecil dari dinding saluran pernapasan seseorang yang keluar pada saat batuk dan bersin. Oleh karena itu, pemerintah melalui penerapan protokol kesehatan menganjurkan kepada masyarakat yang mengalami sakit batuk dan influenza untuk selalu memakai masker, tujuannya untuk membatasi percikan droplet dari yang keluar. Selain itu juga mengatur jaga jarak, agar kemungkinan peluang terpapar penyakit tersebut bisa menjadi lebih kecil. Implikasinya bahwa kegiatan pertemuan atau kerumunan dengan jumlah yang cukup besar harus dihindari. Hal ini sebagai salah satu upaya yang efektif untuk mengurangi penyebaran virus. Oleh karena itu, pembatasan sosial harus diterapkan secara maksimal dalam kehidupan sehari-hari baik di lingkungan kerja ataupun dalam lingkup rumah tangga. Tindakan pencegahan lainnya, berupa selalu mencuci tangan dengan sabun dengan air mengalir, jaga jarak minimal 2 meter, dan tidak melakukan kontak langsung dengan orang lain, serta menghindari kegiatan atau kerumunan yang sifatnya massal (Buana, 2020).

Penanganan wabah pandemi baik dari aspek kesehatan, sosial, politik, ekonomi, dan aspek terkait lainnya sudah dilakukan oleh pemerintah Indonesia. Edukasi, informasi, dan publikasi seputar pencegahan dan penyebaran virus Covid-19 ini juga sudah dilakukan dengan beragam cara dan dengan media cetak dan elektronik. Oleh sebab itu, perlu adanya upaya berupa strategi komunikasi yang disesuaikan dengan kebutuhan dan karakter masyarakat yang dituju. Strategi komunikasi ini dapat dijelaskan sebagai panduan dan perencanaan komunikasi (communication planning) dan manajemen komunikasi (communication manajement) dalam mencapai suatu tujuan tertentu. Strategi komunikasi agar tercapai target dan tujuannya maka harus dapat menunjukkan bagaimana teknis operasionalnya secara tak- 
tis harus dilaksanakan. Selain itu untuk aspek pendekatan tergantung pada waktu, situasi, dan kondisi yang berbeda. (Zahrotunnimah, 2020). Penyebarluasan informasi seputar wabah Corona ini dibutuhkan oleh semua kalangan, baik dari semua golongan usia, status ekonomi, jenis kelamin, demografi dan aspek lainnya. Begitu juga bagi kalangan siswa sekolah dasar, dimana pada usia tersebut informasi dapat menjadi pedoman nantinya baik untuk sekarang dan di masa depan. Diperlukan media yang sesuai dan kondisi, serta dibutuhkan alternatif agar informasi yang disampaikan dapat diterima serta menarik.

Arus globalisasi semakin kuat dimana semakin generasi muda masih mencari jati diri dan tidak tahu banyak tentang makna dibalik seni tradisional warisan leluhur yang kita miliki, walaupun dibalik semua itu ada dalam setiap karya tersebut terkandung norma yang bisa dipelajari dan diterapkan dalam kehidupan (Heriwati et al., 2019). Makin menurunnya nilai-nilai moral yang ada di masyarakat kita yang diturunkan oleh nenek moyang kita sudah makin tergeser oleh budaya barat. Semakin lama semakin budaya hedonism dan individualistis menerpa generasi muda kita. Solusi dalam mencegah hal tersebut, salah satunya melalui seni tradisi yang tentunya dengan adaptasi yang disesuaikan dengan kondisi sekarang $(\mathrm{H}$. Prilosadoso \& $\mathrm{B}$, Suyanto, Rosmiati, Ana., 2017). Membicarakan tentang tembang dalam penelitian ini yang merupakan bagian dari kebudayaan. Terkait dengan kebudayaan, peran dan posisi seni merupakan salah satu unsur dalam kebudayaan dan sebagai fitrah manusia yang diberikan oleh Allah SWT untuk suatu kegiatan yang melibatkan dalam hal kemampuan kreatif sebagai upaya mengungkapkan aspek keindahan, kebenaran dan kebaikan (Waluyo, 2018).

Aktivitas berupa kegiatan bernyanyi, tembang dolanan didalamnya terdapat banyak faktor pada aspek tumbuh kembang anak. Aktivitas ini yang didalamnya terdiri dari aspek belajar sambil bermain dan belajar sambil bernyanyi ini juga bermanfaat untuk diterapkan kepada anak usia dini.

Pemilihan lagu daerah dalam tembang dolanan anak sekaligus untuk melestarikan bahasa tradisi serta mengenalkan warisan nenek moyang kepada anak. Dalam perkembangannya sekitar tahun 80-an, lagu dolanan anak sangat diminati dan dinyanyikan oleh anak-anak khusunya yang berada di wilayah pedesaan. Kegiatan bermain dan menyanyikan lagu dolanan anak di halaman rumah, tanah lapang di desa, lingkungan sekolah, dan lokasi lainnya dimana anak-anak sering berkumpul (Hartiningsih, 2015).

Ajaran serta nilai-nilai dalam kehidupan manusia terkandung dalam tembang dolanan yang juga memiliki keunikan serta daya tarik didalamnya. Bentuk tembang dolanan dan syair yang didalamnya mengandung ajaran moral yang bermanfaat dan bisa diterapkan ke dalam media penyampaian pesan yang bisa diaplikasikan sebagai upaya pelestarian bahasa ibu dan pendidikan budi pekerti (Susilo, 2018). Beragam tembang seperti, misalnya Jamuran, Kupu-Kupu, Cublak-cublak Suweng, Gugur Gunung, Ilir-llir, Menthok-Mentok, Buto Galak, Sluku-Sluku Bathok, Gambang Suling, dan tembang yang lainnya memerlukan kepedulian dari semua pihak, dimana hal ini penting terhadap salah satu bentuk sastra lisan tradisional ini (Yunita, 2014).

Mengapa perlu perhatian akan keberadaan seni tradisi, dikarenakan keberadaannya sudah mulai terpinggirkan akibat salah satunya dampak globalisasi, diman genearsi muda, khususnya mellenial banyak yang merasa tembang dolanan ini sudah kuno dan ketinggalan jaman.

Berdasarkan paparan diatas, selain untuk pengembangan tembang dolanan anak, juga sebagai media alternatif untuk penyebaran dan penanggulangan wabah Corona kepada masyarakat, khususnya siswa sekolah dasar. Maka diperlukan media yang efektif dan sesuai dengan karakter untuk siswa sekolah dasar dengan kolaborasi antara tembang dolanan anak dengan media ilustrasi anak yang bermuatan seputar Covid-19 agar materi informasi dapat diterima oleh kalangan pelajar, khususnya siswa sekolah dasar di Surakarta.

Menurut Dhieni (2005) dalam Prasetyo (2014), menyatakan peranan media melalui buku cerita sangat membantu mengembangkan imajinasi anak terhadap isi cerita atau objek cerita di buku yang terdapat hubungan 
Kolaborasi llustrasi Dan Tembang Dolanan ... Media Edukasi Covid-19 di Surakarta - Basnendar dkk.

sebab-akibat suatu proses yang terjadi pada lingkungan sekitar kehidupan anak, sehingga dapat menyimpulkan isi cerita tersebut berdasarkan kemampuan daya nalar anak setelah membacanya (Prasetyo, 2014). Selain itu menggabungkan seni tradisi berupa tembang dolanan dengan ilustrasi yang sesuai dengan gaya anak diharapkan menjadi perpaduan yang menjadikan pesan di dalam karya tersebut lebih efektif sekaligus melestarikan tembang dolanan di masa sekarang. Seperti kutipan dibawah ini menjelaskan bagaimana seni tradisi perlu pengemasan dan kolaborasi dengan bidang ilmu lainnya.

This condition is inseparable from the existence of traditional arts that do not yet have more modern and newer packaging. Traditional art is increasingly not a favourite choice of society, especially the millennial generation. Most of the favourite arts come from other cultures that are far from traditional values and traditions (B. H. Prilosadoso et al., 2020).

Berdasarkan observasi awal dan melihat situasi saat ini dimana penyebaran virus Corona meningkat, maka didapatkan beberapa rumusan masalah dalam penelitian artistik ini yaitu : bagaimana menciptakan kolaborasi tembang dolanan dan ilustrasi anak yang berisi mengenai pencegahan dan penyebaran virus Covid-19 kepada siswa sekolah dasar di Surakarta.

\section{KAJIAN LITERATUR}

\section{A. Tembang Dolanan Anak Sebagai Media Pendidikan Karakter}

Dewasa ini, arus globalisasi yang dapat dilihat dengan semakin berkembangnya ilmu pengetahuan dan teknologi dengan dampaknya sudah mempengaruhi tatanan kebudayaan bangsa kita. Akibatnya dengan mudah anakanak akan mengalami peristiwa hilangnya jati diri bangsa dan budaya dalam dirinya serta akan menciptakan kebudayaan sendiri. Tembang dolanan sebagai media edukasi sekaligus sebagai pendidikan dengan muatan mengenai karakter sebagai media transformasi nilai-nilai dalam internal kepribadian individu sehingga menjadi satu dalam perilaku di kehidupan dalam masyarakat (Sutedjo, Agus, Prilosadoso, 2016). Tembang dolanan sebagai salah satu wujud kesenian dan kebudayaan Indonesia, telah mengalami pergeseran dan kemunduran akibat adanya arus globalisasi. Saat ini tembang dolanan tersebut sudah jarang dinyanyikan oleh anak-anak. Tembang dolanan bisa dikategorikan sebagai aktivitas menyanyi yang didalamnya banyak faktor yang bermanfaat untuk tumbuh kembang anak. Belajar sambil bermain dan belajar sambil bernyanyi juga tepat diterapkan pada anak usia dini. Melalui aspek musikal, lirik, dan irama dari sebuah tembang dolanan berkaitan dengan perkembangan musikalitas pada anak, sedangkan dari aspek kebudayaan, lagu dolanan dapat memberi manfaat berupa edukasi kepada anak untuk melatih disiplin, nilai harmoni dengan alam lingkungan, sesama manusia, serta orang tua. (Ariesta, 2019). Dari pada materi lagu mengambil lagu berbahasa Indonesia, atau bahasa asing, lebih baik mengambil materi lagu atau tembang dolanan, yang menggunakan bahasa daerah, sekaligus untuk melestarikan bahasa ibu jangan sampai punah. Sekitar era tahun 1980an, perkembangan lagu dolanan dapat dirasakan tumbuh di kalangan anak di wilayah desa. Pada saat itu, anak-anak dapat menyanyikan lagu dolanan dengan ceria baik di pekarangan rumah, halaman sekolah, maupun lokasi tanah lapang yang masih banyak di pedesaan saat itu (Hartiningsih, 2015).

Beberapa pengertian menjelaskan dalam Bahasa Indonesia bahwa tembang disebut lagu yang memiliki lirik/sajak yang didalamnya memiliki irama nada. Sedangkan pengertian tembang dari bahasa Jawa yang berarti tembang, atau tetembangan. Menurut pembagiannya tetembangan, terdapat 4 (empat) jenis, yaitu tembang dolanan, tembang gedhe, tembang tengahan, dan tembang cilik (Maryaeni, 2009). Kandungan dalam tembang dolanan selain penuh dengan ajaran dan nilai-nilai yang adi luhung dalam kehidupan manusia, juga memiliki keunikan dan daya tarik tersendiri. Melalui kandungan ajaran moral dari sebuah tembang dolanan dan syair yang tampak dari visualisasinya, maka berguna sebagai media penyampaian pesan yang dapat diterapkan dalam upaya pendidikan budi pekerti serta usaha untuk pelestarian bahasa ibu (Susilo, 2018). 
Merujuk tulisan Maryaeni (2009) menjelaskan bahwa seperti halnya seni pertunjukan, tembang dolanan memiliki dua fungsi primer dan sekunder (Soedarsono, 1985). Terdapat 3 (tiga) fungsi primer tembang dolanan yaitu, (1) bersifat ritual, (2) estetis (tontonan), dan (3) sebagai hiburan pribadi (Maryaeni, 2009). Sedangkan penjelasan dari fungsi sekunder menurut Danandjaja (1984: 80-89), yaitu (1) sebagai alat pendidikan masyarakat, (2) alat penebal perasaan solidaritas kolektif, (3) alat yang memungkinkan seseorang dapat bertindak bijaksana sesuai dengan kedudukan dan kekuasaan terhadap pelanggaran, (4) alat untuk media protes terhadap ketidakadilan yang terjadi di dalam masyarakat, (5) memberi kesempatan kepada seseorang melarikan diri untuk sementara dari kehidupan nyata yang membosankan ke dunia khayal yang indah yang terjadi di masyarakatnya, dan (6) pengendali terhadap pelanggaran norma-norma yang berlaku pada masyarakatnya (Maryaeni, 2009). Apabila Tembang dolanan Jawa merupakan salah satu sarana komunikasi dan sosialisasi anak dengan lingkungannya. Tembang menjadi salah satu cara untuk mempengaruhi seseorang dalam melakukan suatu tindakannya.

Media bersosialisasi, bergembira, dan bersuka cita dengan sahabat dan kawan sebaya bisa melalui lagu dolanan, baik berupa bermain, bernyanyi, serta beraktifitas secara fisik. Pesan pendidikan moral dan petuah yang terkait dalam aktivitas kehidupan seorang anak terkandung dalam sebuah lirik lagu dolanan. Dampak yang ditimbulkan oleh pengaruh lagu dapat mempengaruhi komunikasi dalam meningkatkan kemampuan Bahasa sesorang (Retnoningsih, 2019).

Maka dengan tinjauan pustaka di atas, maka penelitian artistik akan mencoba menciptakan tembang dolanan anak dengan konten yang disesuaikan kondisi dan situasi saat ini, wabah Corona yang menjangkiti masyarakat kita. Lewat penelitian artistik ini akan mengkolaborasikan antara tembang dolanan dengan disertai buku ilustrasi anak yang akan berisi mengenai informasi seputar Covid-19, penyebaranannya, dan maupun pencegahannya kepada siswa sekolah dasar.

\section{B. Peran llustrasi sebagai Media Edukasi Untuk Anak}

Perkembangan kehidupan manusia telah diawali sejak individu masih dalam kandungan sampai menginjak usia dewasa. Tahapan-tahapan tersebut saling berkaitan dalam satu kesatuan yang utuh. Tahapan perkembangan individu anak diawali dari refleks kemudian perkembangan susunan syaraf pusat dan berkembangnya fungsi lain, antara lain : motorik, emosi, inteligensia dan sosial (Olivia et al., 2019).

Media memiliki arti yang luas dimana kebanyakan orang akan mengartikan menurut konten yang akan dibahas. Mediapun dapat dikatakan komunikasi antar dua orang atau lebih yang saling berinteraksi agar apa yang disampaikan salah satu pihak dapat dimengerti oleh pihak yang lainnya. Media bisa dikatakan sebagai penghantar untuk menyampaikan maksud dari seseorang ke orang lain agar dapat dipahami dengan mudah.

Media pembelajaran untuk anak, salah satunya melalui buku cerita yang baik, yang mana buku tersebut harus didukung oleh gambar ilustrasi yang baik juga agar lebih menarik perhatian pembaca khususnya anak-anak. llustrasi yang terdapat dalam bacaan anak tidak hanya semata-mata berfungsi sebagai pelengkap teks, namun justru menjadi satu kesatuan yang mendukung cerita karena ilustrasi berfungsi untuk menggambarkan kejadian atau peristiwa yang diceritakan dalam buku cerita.

Pengajaran akan lebih efektif dan dapat diterima apabila objek dan kejadian yang menjadi bahan pengajaran dapat divisualisasikan secara realistik menyerupai keadaan yang sebenarnya, namun tidaklah berarti bahwa media harus selalu menyerupai keadaan sebenarnya (Prilosadoso, B. H, Sutedjo, Agus., Soewasta, 2017). Selain itu, ilustrasi dapat memberikan gambaran secara grafis dari objek yang ada di dalam buku cerita (Prasetyo, 2014).

Pengertian ilustrasi menurut Rasjoyo (1994: 63) dalam Kristanto, memaparkan bahwa kata ilustrasi secara etimologi berasal dari bahasa latin Illustrate yang memiliki arti men- 
Kolaborasi llustrasi Dan Tembang Dolanan ... Media Edukasi Covid-19 di Surakarta - Basnendar dkk.

jelaskan atau menerangkan sesuatu (Kristanto, 2011) because it is visual, can be seen, komonikatif, informative and easy to understand. From an early age, children need to be equipped with a learning culture through children's story books - children who are Illustrative as investment value - the value of culture in children - children who can protect themselves and respond to the challenges of globalization both present and future.", "author":[\{“dropping-particle".",", "family":"Kristanto", "given":"”, ,"non-dropping-particle".",", "parse-names":false, "suffix":"'"\}],"container-title":"Malih Peddas", "id":"ITEM-1", "issue":"2", "issued":\{“date-parts":[["2011"]]\},"pag e":"61-72","title":"Gambar Ilustrasi Buku Cerita Anak-Anak Sebagai Pelestarian dan Pengembangan Budaya di Era Globalisasi","type":"article-journal", "volume":"1"], "uris":["http:// www.mendeley.com/documents/?uuid $=d$ $6 f 8172 e-9 d d 3-41 b 4-b 8 d 5-9 c 7 e d-$ 636daaa"]\}],"mendeley":\{"formattedCitation":"'(Kristanto, 2011).

Sedangkan definisi ilustrasi dalam arti yang lebih luas bahwa suatu karya seni rupa yang bertujuan memperjelas sesuatu atau menerangkan sesuatu yang dapat berupa cerita atau naskah, musik atau gambar. Ilustrasi secara dalam perkembangannya tidak hanya bermanfaat sebagai sarana pendukung sebuah cerita tetapi dapat juga berfungsi untuk menghiasi ruang kosong dalam penerapannya, misala dalam majalah, koran, buku, tabloid, packaging, label kemasan, dan lain-lain. Masyarakat pada umumnya yang tidak mengetahui ilmu tentang desain, salah satunya unsurnya yaitu ilustrasi, maka dalam pikiran mereka pasti akan bertanya-tanya mengenai tentang gaya desain (Astuti \& Rosmiati, 2019). Ilustrasi mampu memberikan nilai positif terhadap apresiator dengan hadirnya sebuah gaya ilustrasi. Menurut Shulevitz (1985) dalam Gilang, dkk (2017) mengemukakan bahwa setiap anak-anak akan melihat dahulu ilustrasi di dalam sebuah buku pada saat membelinya. Pengertian ilustrasi dapat dipaparkan secara umum ada 3 (tiga) jenis, yaitu: (1) gambar berupa foto atau lukisan untuk membantu memperjelas isi buku; (2) gambar, desain, atau diagram untuk penghias halaman sampul; dan (3) penjelasan tamba- han berupa contoh untuk lebih memperjelas paparan tulisan (Gilang et al., 2017).

Seni gambar yang dipakai untuk memberi penjelasan atas suatu tujuan tertentu ataupun maksud tertentu dan penjelasan tersebut disampaikan secara visual bisa juga dijelaskan juga dapat sebagai pengertian ilustrasi. Kemampuan ilustrasi dalam komunikasi sebagai media terjemahan dari teks, serta membantu mengkomunikasikan suatu pesan dengan tepat, cepat serta tegas. Proses ilustrasi akan melibatkan ide untuk menentukan cerita, tokoh, latar, dan latar belakang (B H Prilosadoso, B Pujiono, 2019). Kemampuan yang lainnya dari sebuah ilustrasi sebagai kekuatan untuk membentuk suasana yang penuh emosi dan membuat suatu gagasan yang ingin disampaikan kepada pembaca menjadi seolah-olah nyata. Kehadiran sebuah ilustrasi berfungsi juga bahwa pesan dalam teks dapat lebih berkesan, hal ini dikarenakan pembaca memahami dan lebih mudah membaca. (Maharsi, 2016).

\section{METODE PENELITIAN}

Penelitian artistik ini dengan alokasi waktu sekitar 6 (enam) bulan dengan lokasi di wilayah Surakarta ini menggunakan metode penelitian diskriptif kualitatif karena dalam penelitian yang bertujuan ini untuk mendeskripsikan secara mendalam tentang objek penelitiannya (Heriwati et al., 2019). Berdasarkan hal diatas, penelitian ini menggunakan dua tahapan penting didalamnya, yaitu metode pengumpulan data dan analisis data.

\section{A. Sumber Data}

Penelitian ini akan mengambil sumber data yang relevan untuk mendukung pelaksanaan dar tahapan awal, perancangan, sampai tahap ekseskusi melalui beberapa aspek, seperti dibawah ini :

1. Materi seputar virus Covid-19 yang digunakan sebagai sumber ide dan materi utama dalam menciptakan tembang dolanan dan buku ilustrasi anak.

2. Penelitian artistik ini sebagai sumber referensinya didapat dari beragam sumber baik dari penelitian yamg dilakukan 
sebelumnya, artikel ilmiah, buku teks, media massa, dan sumber lainnya.

3. Wawancara dilakukan untuk mendapatkan data sekaligus pengalaman yang sudah dilakukan sebelumnya untuk memaksimalkan dalam penelitian baru Informan yang dipilih yang terkait langsung obyek penelitian, meliputi : pengrawit, akademisi, seniman, dan illustrator.

\section{B. Teknik Pengumpulan Data}

Melalui aspek kajian literatur mengenai virus Covid-19, tembang dolanan, buku ilustrasi, dan aspek lainnya, observasi lapangan, wawancara narasumber, pendokumentasian, dan pencatatan sebagai tahapan dalam teknik pengumpulan data dalam penelitian ini.

\section{Model Analisis}

Model interaktif digunakan dalam proses analisis dari data yang dikumpulkan lewat kajian literature dan wawancara. Sedangkan komponen tahapan dalam analisis meliputi tahapan pengumpulan data, reduksi data, sajian dan penarikan kesimpulan. Seperti sebuah tahapan siklus yang saling berinteraksi antar komponen tersebut sampai dengan keterangan yang disusun selengkap-lengkapnya sehingga proses mekanisme analisis menjadi benar.

\section{Perencanaan dan Perancangan Karya}

Karya seni hasil kolaborasi antara seni karawitan dan buku ilustrasi ini dirancang sebagai media pembelajaran kepada siswa sekolah dasar dengan materi seputar virus Corona, baik informasi pencegahan dan penyebaran wabah pandemi yang mewabah di Indonesia saat ini. Tahapan penelitian ini dilakukan dalam beberapa tahap, yaitu : tahapan masalah pemecahan, tahap perencanaan, tahap desain, tahap uji coba, dan tahap akhir penyebaran. Metode design thinking digunakan untuk metode analisis dalam penciptaan karya kolaborasi ini. Sebagai bagian dari unsur design thinking yang diadaptasi dari dari dua literatur yang kemudian dikembangkan oleh perancang sesuai kondisi dan kebutuhan dengan tahapan (Sutanto. Jessica, P, Cok Gede, Tedjokoesoemo, 2017), seperti dalam penjelasan dibawah ini.

\section{a. Discovery}

Panduan dan pegangan dari pertanyaan-pertanyaan agar tetap sesuai pedoman dan tidak keluar dari tujuan perancangan baik berupa wawancara dan proses pengumpulan literatur dari sumber dengan tingkat validitas baik, baik data mengenai virus Corona, tembang dolanan, maupun ilustrasi anak. Hasil tahap ini berupa analisa teori dan hasil survei lapangan. Mencari atau memilih tema pada setiap tembang dan ilustrasi anak yang ingin diciptakan yang ditujukan media edukasi mengenai pencegahan dan penanggulangan wabah ini.

b. Interpretation

Analisis interpretasi ini untuk mengambil benang merah dimana berupa kesimpulan dalam tahap discovery, kemudian dibuat berupa framework. Penerapan tahapan ini dalam penciptaan karya berupa tahapan menyusun cakepan (teksnya) dalam bentuk bebas atau bentuk macapat dan membuat atau memilih lagu yang sesuai dengan teksnya, serta draft storyline ilustrasi anak.

\section{c. Ideation}

Memanfaatkan hasil dari tahap sebelumnya, maka pada analisa ideation untuk membuat beberapa karya alternatif baik karya tembang dolanan anak dan ilustrasi sebagai pilihan atau alternatif dengan konstruksi sesederhana mungkin. Merancang bentuk gendhing dan instrumentasinya, serta rancangan komprehensif ilustrasi anak.

\section{d. Experimentation}

Proses pembuatan eksperimen dimana selama proses penciptaanya memungkinkan untuk terjadi perubahan karya. Hasil dari eksperimen dianalisa dan diuji coba untuk kemudian diperbaiki kembali menjadi luaran akhir. Proses penuangan/latihan dengan vokalis dan pengrawit, serta pembuatan final artwork ilustrasi anak.

\section{e. Evolution}

Tahap evolution, karya seni yang telah dikembangkan dan sudah melalui tahap eksperimen dipilih satu untuk diproduksi. Pengembangan dari karya seni tersebut masih bisa 
terjadi pada tahap ini. Untuk tembang dolanan melakukan rekaman materi yang sudah dirasa matang dan ilustrasi anak sudah siap dicetak.

\section{f. Implementation}

Tahapan ini bertujuan untuk menerapkan kolaborasi antara penciptaan tembang dolanan dengan ilustrasi sebagai pendukung tampilan tembang tersebut agar lebih menarik pembaca, khususnya siswa sekolah dasar. Agar lebih mudah pemahaman, maka untuk lebih jelasnya dapat dilihat bagan alir penciptaan karya seni, seperti di bawah ini.
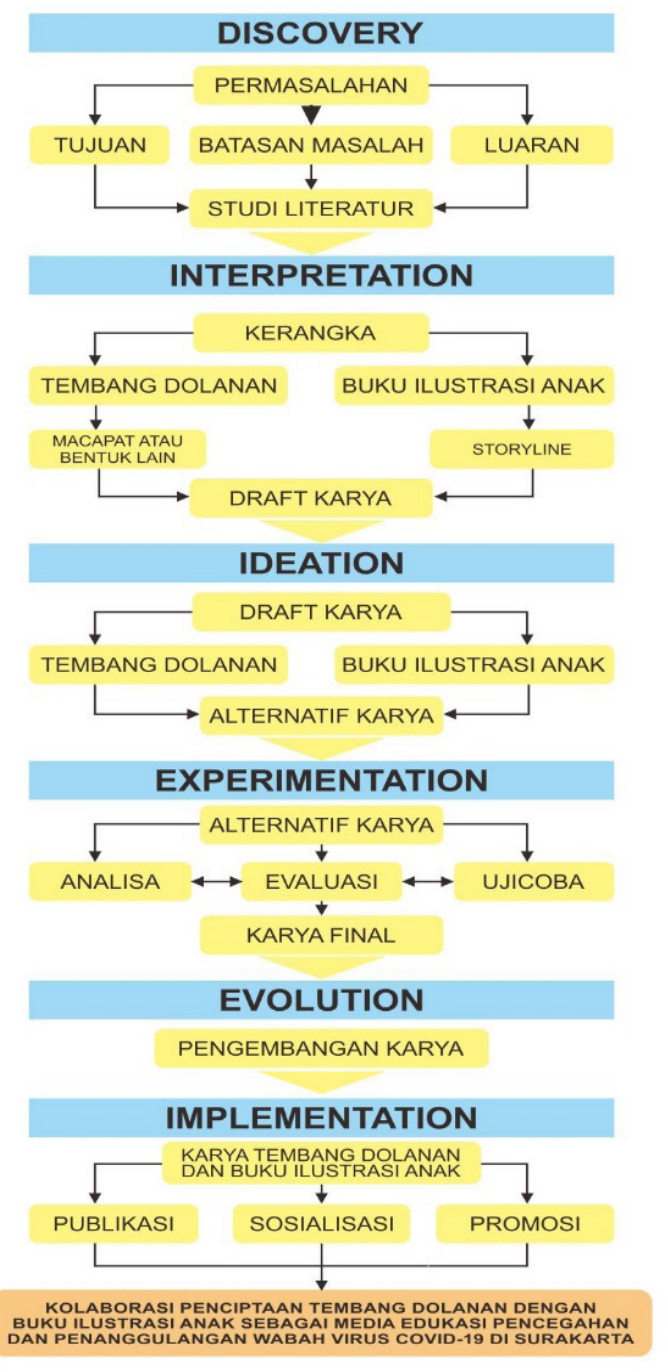

Gambar 2. Bagan Alir Penciptaan Karya Seni Sumber : Diolah dari berbagai sumber, 2020

\section{HASIL DAN PEMBAHASAN}

Bagian ini akan memaparkan dua proses perancangan yaitu perancangan untuk tembang dolanan dan ilustrasi anak sebagai media kolaborasi media edukasi pencegahan virus Corona yang akan dijelaskan sebagai berikut :

\section{A. Perancangan Tembang Dolanan Anak Edukasi Covid-19}

Tembang dolanan yang disusun dalam rangka sebagai perpaduan seni tradisi dan juga sebagai media edukasi pencegahan dan penanggulangan wabah virus Covid-19 yang semakin meningkat grafiknya baik jumlah pasien yang terpapara maupun yang meninggal akbat wabah pandemi tersebut. Berikut proses dari awal sampai tahapan akhir penyusunan tembang dolanan anak yang bertema seputar kondisi Covid-19, dimana dalam prosesnya dapat menghasilkan 6 (enam) tembang dolanan anak, yaitu :

1) Tembang Dolanan “Gusti”-Pelog Nem,

2) Tembang Dolanan "Prei Ra Sekolah"-Pelog Nem,

3) Tembang Dolanan "Virus Corona"-Slendro Manyura,

4) Tembang Dolanan "Ayo Kanca"-Slendro Manyura,

5) Tembang Dolanan "Kangen Sekolah" -Pelog Barang,

6) Tembang Dolanan "Waspada"- Pelog Barang.

Proses tahapan dapat dijelaskan dibawah ini, baik mulai latar belakang ide, gagasan, penyusunan syair, sampai proses editing, dapat dijelaskan dibawah ini dengan mengambil salah satu proses perancangan tembang dolanan dan ilustrasi :

\section{Tembang Dolanan "Kangen Sekolah", Lancaran Laras Pelog Pathet Barang}

Penyusunan tembang dolanan dengan judul Kangen Sekolah, dilatarbelakangi dari sebuah pengamatan terhadap dampak dari pandemi virus Corona terhadap pelaksanaan pembelajaran di negara kita, dari tataran perguruan tinggi sampai tataran PAUD. 
Dalam kesempatan ini lebih difokuskan pada pelaksanaan proses pembelajaran di tingkat Sekolah Dasar (SD). Kekhawatiran akan semakin menyebarnya virus Corona khususnya pada anak SD, maka pemerintah dalam hal ini Kementerian Pendidikan dan Kebudayaan mengambil kebijakan mewajibkan pelaksanaan pembelajaran dengan sistem daring terutama pada sekolah-sekolah yang berada pada wilayah zona merah.

Wujud dari kebijakan ini adalah dilaksanakannya semua proses belajar mengajar dilakukan secara daring dengan menggunakan beberapa macam piranti pembelajaran oneline sesuai kesepakatan antara guru dan orang tua murid. Keadaan murid yang tidak pergi ke sekolah dalam waktu yang cukup lama dalam bahasa Jawa disebut prei, dan dengan segala dinamika permasalahannya menggelitik penyusun untuk menjadikannya sebagai ide gagasan dari salah satu karya tembang dolanan anak dalam penelitihan artistik ini dengan judul Kangen Sekolah.

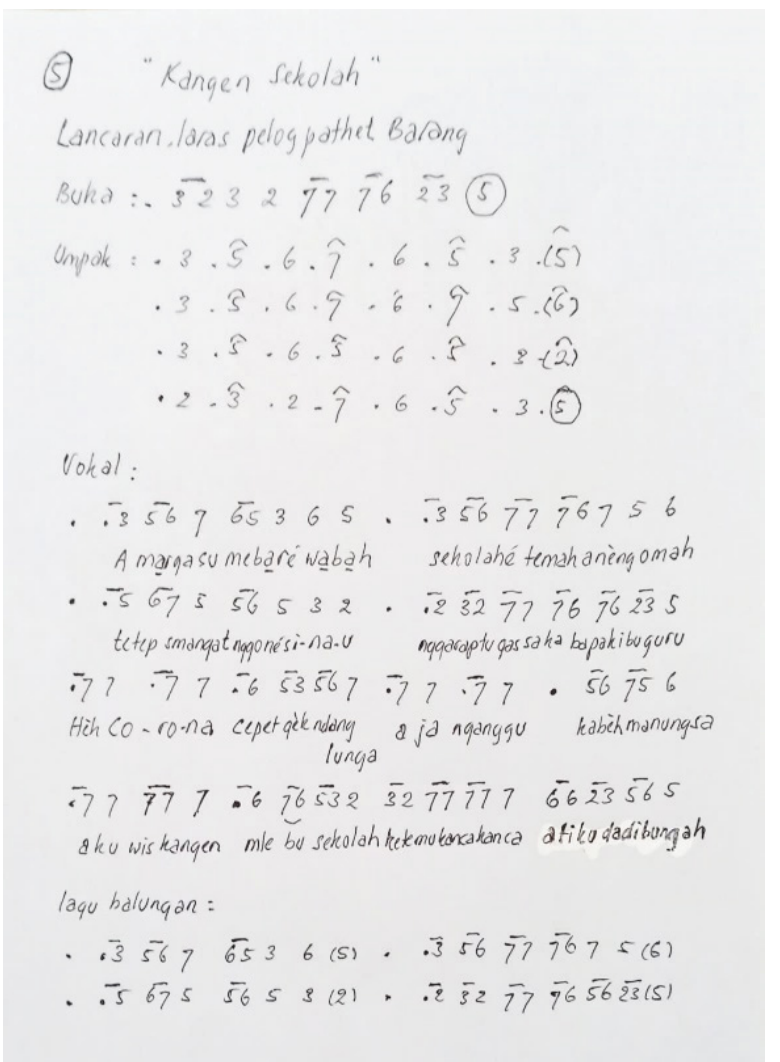

Gambar 3. Draft Penyusunan Tembang Dolanan Kangen Sekolah (Sumber : Waluyo, 2020)
Tahapan dalam menyusun tembang dolanan dengan judul Kangen Sekolah diawali dengan membuat cakepan atau teks dalam bahasa Jawa. Cakepan dalam tembang dolanan Kangen Sekolah berisi tentang nasehat kepada anak-anak saat lama tinggal di rumah, bahwa semua itu karena menyebarnya wabah virus Corona, yang menjadikan sekolah hanya dari rumah. Namun demikian anak-anak hendaknya tetap semangat dalam belajar, dengan mengerjakan semua tugas dari bapak ibu guru. Senantiasa berdoa semoga virus ini cepat pergi, dan tidak mengganggu semua manusia. Sadar betul bahwa anakanak sudah rindu masuk sekolah, bertemu dengan teman-teman sehingga bisa bermain bersama dalam kebahagiaan. Nasehat ini kemudian disalin dalam bahasa Jawa dengan memilih kata-kata yang mudah dipahami terutama oleh anak-anak SD di wilayah daerah yang menggunakan bahasa Jawa sebagai cakepan dalam tembang dolanan Kangen Sekolah.

Setelah teks/cakepan tersusun proses berikutnya adalah menyusun lagu yang sesuai dengan karakter atau suasana teks dan konteks cakepannya yang menggambarkan kerinduan anak-anak pada teman dan bapak ibu gurunya, dalam suasana belajar di sekolah. Dalam menyusun lagu pada tembang dolanan Kangen Sekolah ini, dicari beberapa kemungkinan baik dari aspek bentuk dan teknis sajian tembangnya, laras yang digunakan, dan juga pemilihan tempo penyajiannya. Dari aspek bentuk tembang, laras, dan teknis penyajiannya dipilihlah lagu dalam laras pelog pathet barang, dengan memilih teknis sajian vokal gerongan dengan tempo yang cepat dan dinamis.

Tahap berikutnya adalah memilih bentuk gending yang akan mewadahi cakepan dan lagu yang sudah tersusun. Melalui proses perenungan secukupnya, maka bentuk gending yang dirasa pas untuk tembang Kangen Sekolah, adalah lancaran dalam irama lancar, dengan tempo yang cepat, dengan menggunakan umpak 
balungan nibani dan juga dalam balungan ngadhal yang melagukan bagian penting dari lagu pokoknya, dan setelah sirep, tabuhan instrumen balungan dan slenthem disesuaikan dengan seleh-seleh lagu tembangnya.

Atas pertimbangan cakepan dan lagu yang telah tersusun dalam suasana yang dinamis, instrumen yang dipilih untuk memperkuat ekspresi lagunya adalah instrumen dari gamelan ageng dalam laras pelog barang. Instrumen tersebut antara lain : Kendhang ciblon, Bonang barung, Gender barung, Slemthem, Demung, Saron barung, Saron penerus, Kethuk, Kenong, Kempul dan Gong.

Tahapan berikutnya adalah uji coba lagu dengan teknik gerongan tembang dolanan Kangen Sekolah kepada murid sekolah dasar yang diwakili oleh 2 (dua) murid, terdiri dari 1 (satu) murid putra, dan 1 (satu) murid putri dalam sesi garingan (tanpa gamelan).

Tahap uji coba ini dimulai dari mengenalkan tangga nada pelog barang kepada ke dua murid SD tersebut, kemudian dilanjutkan dengan mencoba memvokalkan tangga nada pelog barang, baru kemudian dikenalkan lagu tembang dolanan Kangen Sekolah dengan membaca cakepannya secara benar seperti dalam foto dokumentasi berikut ini.

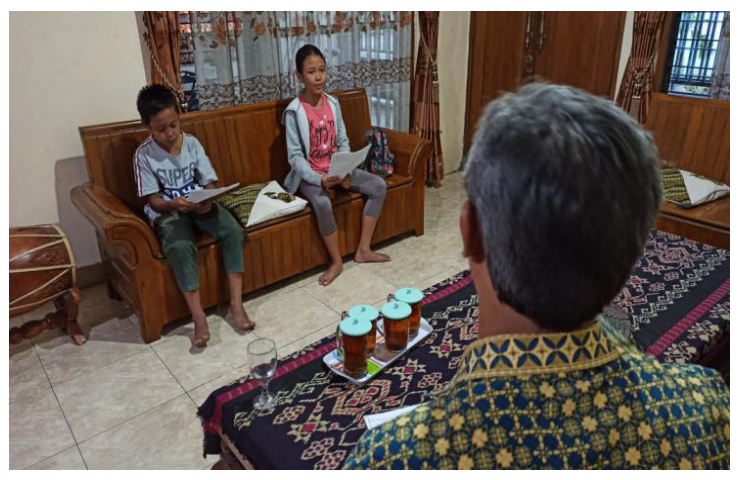

Gambar 4. Uji Coba Teknik Gerongan Tembang Dolanan Kangen Sekolah Sumber : Dok Pribadi, 2020

Setelah itu dilanjutkan latihan praktek menyajikan tembang dolanan Kangen Sekolah baris demi baris, sampai lagu ini bisa disajikan dengan lancar dan tepat baik dari aspek pembacaan cakepan, lagu, tempo penyajian, dan ekspresinya.

Tahapan berikutnya adalah penuangan secara keseluruhan dalam bentuk latihan bersama antara vokal anak-anak dan pengrawit yang terdiri dari mahasiswa jurusan karawitan di studio F Fakultas Seni Pertunjukan ISI Surakarta. Dalam tahap ini penyusun memberi penjelasan dahulu perihal garap dan jalannya sajian gending dalam tembang dolanan Kangen Sekolah, dengan menyediakan dulu notasi yang telah dibagikan sebelum latihan dimulai.

Setelah dirasa cukup bisa dipahami garap dan jalannya sajian dari gending tembang dolanan ini baik oleh pengrawit dan vokalisnya, segera dimulai latihan bersama antara instrumen dan vokalnya, sampai dirasa sudah lancar dan benar maka segera dilakukan rekaman langsung.

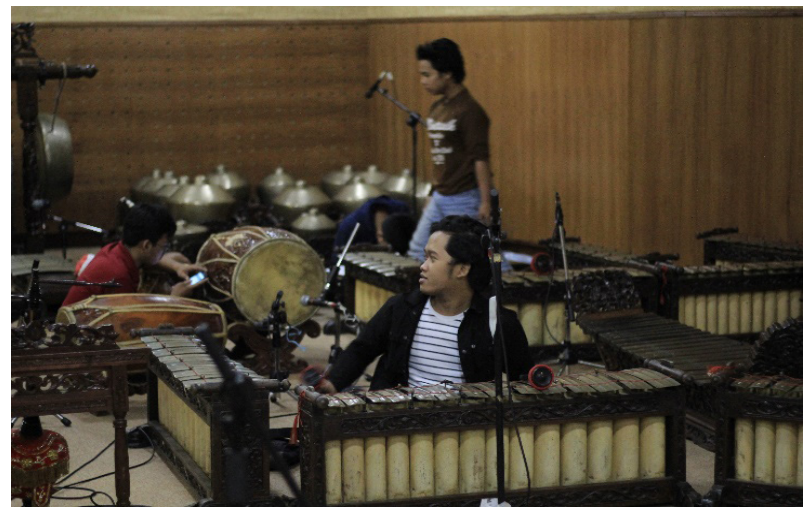

Gambar 5. Proses Mixing Tembang Dolanan Kangen Sekolah di Studio Karawitan Sumber : Waluyo, 2020

Tahap berikutnya setelah dilakukan rekaman kemudian dilanjutkan proses editing oleh dari unit Ajang Gelar ISI Surakarta. Hasil karya Tembang dolanan Kangen Sekolah yang berupa rekaman audio dan notasinya dijadikan sebagai bukti dalam pembuatan laporan penelitihan artistik ini. Notasi dan jalannya sajian dapat dilihat dari penjelasan dibawah ini : 


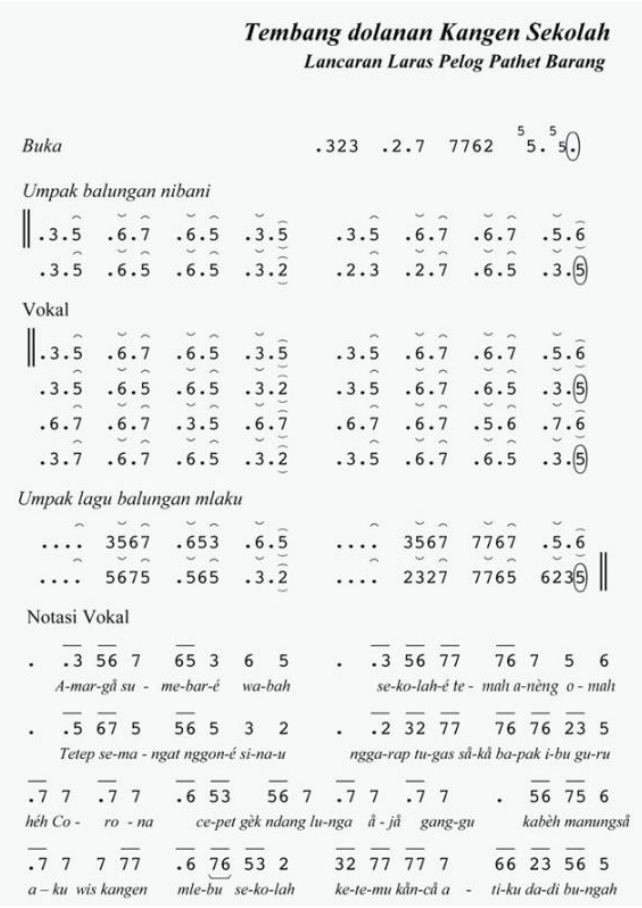

Gambar 6. Tembang Dolanan Kangen Sekolah Sumber : Waluyo, 2020

Keterangan jalan sajian :

1. Buka bonang

2. Umpak disajikan satu kali, menjelang gong digarap sirep.

3. Bagian lagu atau vokal rambahan 1

4. Umpak lagu balungan

5. Bagian lagu atau vokal rambahan 2

6. Balungan nibani terus suwuk gropak.

\section{B. Perancangan Ilustrasi Tembang Dolanan Anak Media Publikasi Edukasi Covid-19}

Perancangan karya berupa ilustrasi anak yang berisi materi penjelasan tembang dolanan sebagai media publikasi yang efektif dan efisien mengenai virus Covid-19 kepada siswa sekolah dasar, dimana sebagai bagian penerapan ilmu desain komunikasi visual yang mengandung unsur-unsur visual. Perancangan ilustrasi tembang dolanan anak menggunakan konsep penciptaan diatas dapat dijelaskan, seperti dibawah ini.

\section{Discovery}

Karakter ilustrasi yang diguakan menggunakan gaya visual yang disukai oleh anak-anak. Karakter ilustrasi dihasilkan setelah melalui pengumpulan data yang akan menjadi pegangan agar tidak keluar dari tujuan perancangan dan mencari atau memilih tema ilustrasi anak yang ingin diciptakan. Seperti dalam gambar dengan penyusunan outline karakter berikut ini.

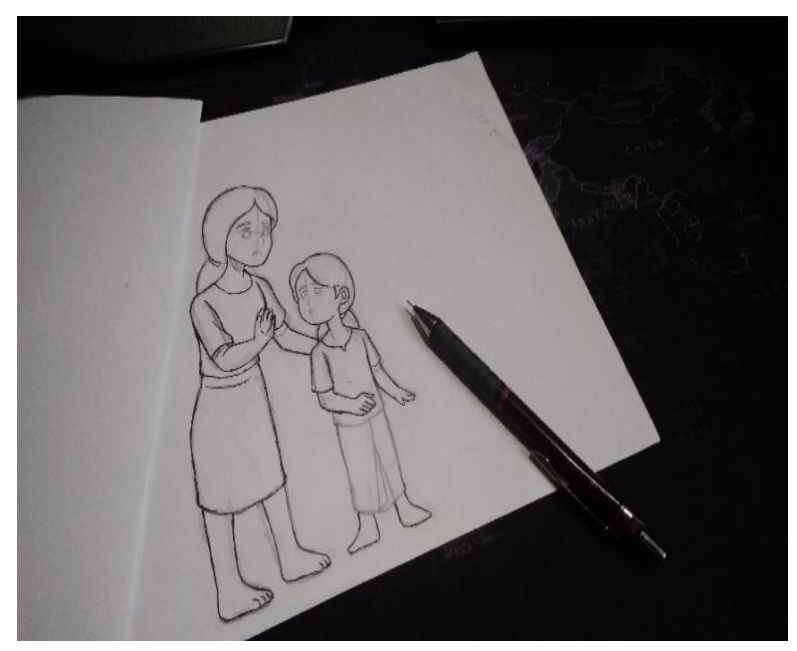

Gambar 7. Proses Sketsa Karakter dan Gaya Ilustrasi

Sumber : Romanov, 2020

\section{Interpretation}

Penyesuaian tema dari tembang dengan ilustrasi yang dipakai dalam karya ini dihasilkan dari proses analisa interpretasi. Pada tahapan ini yang dilakukan adalah draft storyline ilustrasi anak. Tahapan ini interprestasi antara syair tembang dolanan yang sudah disusun dengan ilustrasi yang disesuaikan agar antara keduanya bisa harmonis. Proses tersebut dapat dilihat dalam gambar dibawah ini.

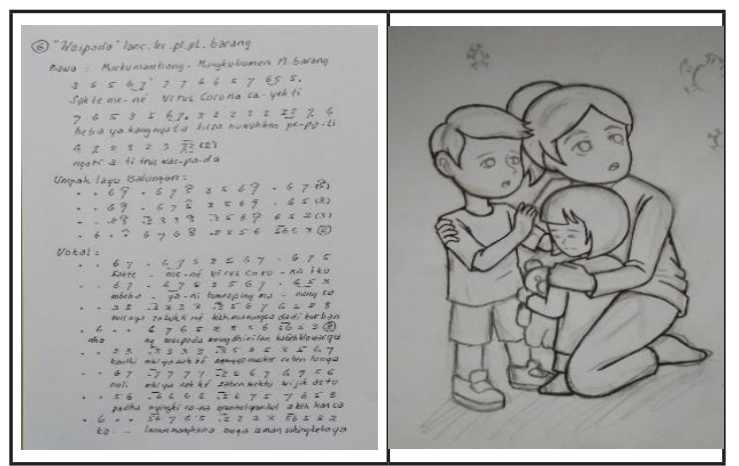

Gambar 8. Proses Sketsa llustrasi Berdasarkan Syair Tembang Dolanan Sumber : Romanov, 2020 


\section{Ideation}

Proses pembuatan alternatif ilustrasi dalam tahapan Ideation ini untuk berfungsi sebagai pilihan atau alternatif dengan konstruksi sesederhana mungkin, seperti dalam gambar dibawah ini.

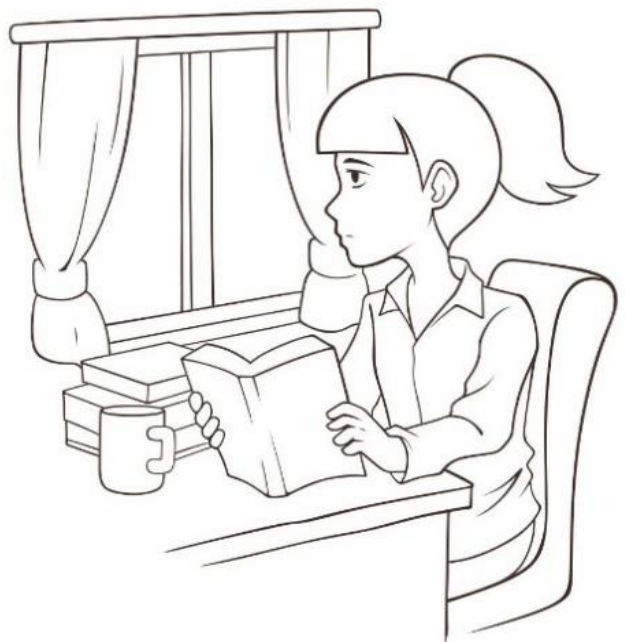

Gambar 9. Proses Outline Ilustrasi Sumber : Romanov, 2020

\section{Experimentation}

Proses pembuatan eksperimen dari ilustrasi, hasil dari eksperimen dianalisa dan diuji coba untuk kemudian kemudian diperbaiki kembali menjadi luaran akhir. Tahapan ini melalui pengerjaan digital imaging dengan software Adobe Photoshop, seperti dalam foto berikut.

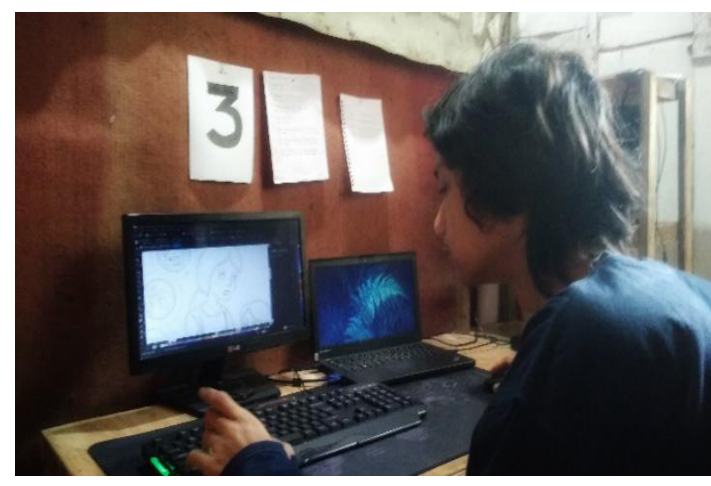

Gambar 10. Proses Digitalisasi llustrasi Sumber : Romanov, 2020

\section{Evolution}

Tahap evolution, draft karya seni yang telah dikembangkan dan sudah melalui tahap eksperimen dipilih satu untuk diproduksi. Pengembangan dari karya seni tersebut masih memungkinkan pada tahap ini.

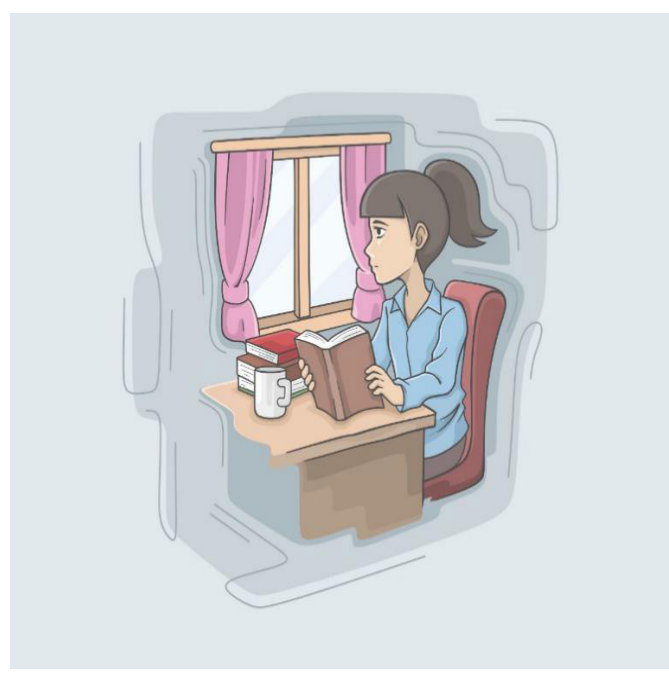

Gambar 11. Proses Akhir llustrasi Sumber : Romanov, 2020

\section{Implementation}

Tahap implementation bertujuan untuk mempromosikan dan mempublikasikan karya seni yang telah dibuat. Berikut contoh karya dari ilustrasi tembang dolanan anak Tembang Dolanan "Kangen Sekolah" - Pelog Barang, seperti dibawah ini : 


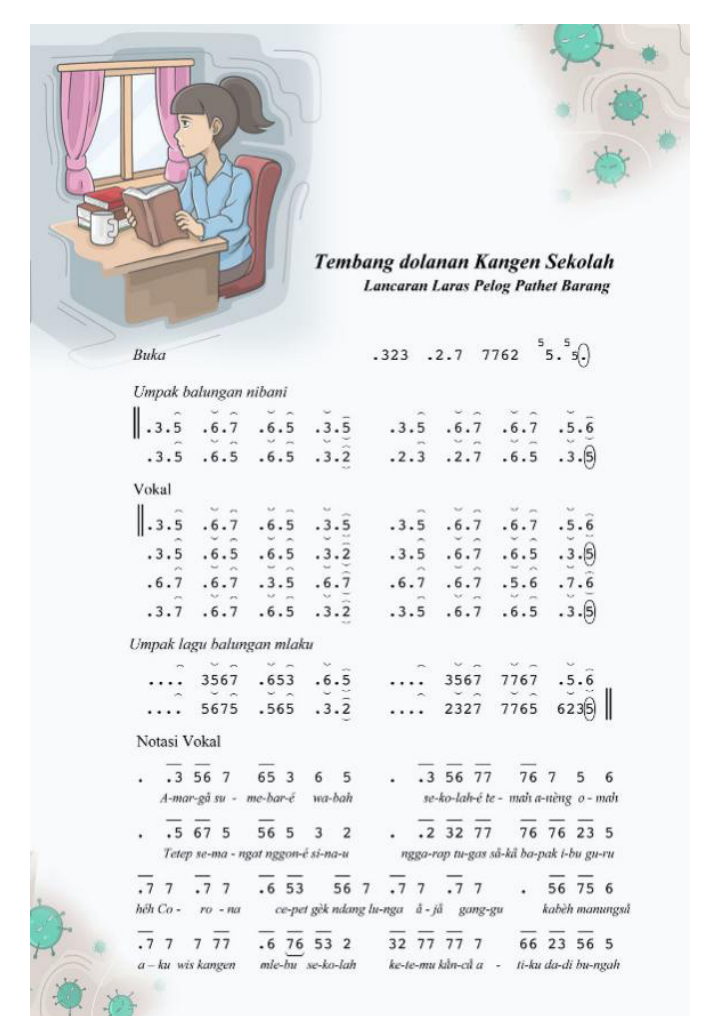

Gambar 12. Karya llustrasi Tembang Dolanan Anak "Kangen Sekolah"

Sumber : Basnendar H, 2020

\section{KESIMPULAN}

Karya artistik ini sebagai bentuk kolaborasi dari karawitan dengan ilustrasi sebagai media edukasi akan materi pencegahan dan penanggulangan virus Covid-19, sebagai media alternatif khususnya kepada siswa sekolah dasar. Karakter masyarakat yang dituju akan memberi perbedaan dalam karya ini. Penyesuaian yang sesuai kondisi wabah, juga pesan dari makna tembang dolanan, dan ilustrasi yang menarik serta informatif agar semua karya bisa diterima. Karya ilustrasi tembang dolanan anak ini menggunakan unsur-unsur visual yang diperlukan dalam menghasilkan suatu tampilan visual, berikut penjelasannya :

\section{a. Garis}

Garis dalam karya ilustrasi sebagai elemen visual yang dapat dipakai dimana saja dengan tujuan memperjelas dan mempermudah pembaca. Garis yang sederhana dalam karya ini agar memudahkan pembaca melihat dan mengerti situasi dalam tembang dolanan anak ini.

\section{b. Bidang}

Ilustrasi ini menggunakan bidangbidang bidang tak beraturan (nongeometris) agar memiliki kesan santai, dinamis, dan tidak formal, Fungsi pemberian bidang kosong dalam karya ini dimaksudkan untuk menambah minat dan kenyamanan membaca dalam menikmati syair tembang dolanan anak yang bertemakan Covid-19.

\section{c. Warna}

Daya tarik dalam hal ilustrasi, yaitu warna, dimana salah satu elemen visual ini yang berfungsi untuk menarik perhatian pembaca. Penggunaan warna tersier (tertiary colors), merupakan campuran antar warna primer dan warna sekunder, yaitu, biru-ungu dan biru-hijau lebih dominan dalam karya ini. Selain itu unsur value yang merupakan terang-gelapnya warna, dimana semua warna dapat dikurangi atau diperlemah kekuatannya dengan cara dibuat lebih terang atau lebih gelap diterapkan dalam karya ini.

\section{d. Gelap Terang}

Kontras value dalam desain komunikasi visual di karya ilustrasi ini dapat digunakan untuk menonjolkan pesan atau informasi, sekaligus menciptakan citra. Penggunaan warnawarna yang kurang kontras (low contrast value) dapat menciptakan kesan kalem, damai, statis, dan tenang sesuai dengan pesan dalam ilustrasi dan kondisi wabah yang belum selesai dan mereda.

\section{e. Format}

Ilustrasi yang memperhitungkan unsur besar-kecilnya elemen visual perlu diperhitungkan secara cermat sehingga tampilan dalam karya ilustrasi tembang dolanan anak ini memiliki nilai kemudahan baca (legibility) yang tinggi, sehingga pesan dan ketertarikan untuk membaca, menyanyikan serta melakukan pesan baik dalam syair dan ilustrasi tembang dolanan anak bertema Covid-19 ini diterima oleh siswa sekolah dasar pada khususnya.

Beberapa kendala yang menghambat dalam proses ini tentunya masih adanya pera- 
turan protokol kesehatan serta alokasi waktu pembuatan karya yang sedikit terhambat, namun secara umum perancangan karya artistik ini dapat berjalan tepat waktu. Karya kolaborasi ini masih dapat dikembangkan dan dimaksimalkan dengan kolaborasi dari lintas bidang ilmu, sehingga akan ditemukan inspirasi atau gagasan yang lain, khususnya dalam memberi edukasi, informasi, sekaligus rekreasi kepada masyarakat akan pencegahan dan penanggulangan Covid-19 ini.

\section{DAFTAR PUSTAKA}

Ariesta, F. W. (2019). Nilai Moral Dalam Lirik Dolanan Cublak-Cublak Suweng. IImu Budaya Cakrawala, 7(2), 188-192. https:// doi.org/http://dx.doi.org/10.34050/jib. v7i2.7104

Astuti, T. P., \& Rosmiati, A. (2019). Gaya Desain Cover Buku Karya Djenar Maesa Ayu Tahun 2016. Texture, Art \& Culture Journal, 2(1), 61-73. https://jurnal.isi-ska.ac.id/ index.php/TXT/article/view/2656

B H Prilosadoso, B Pujiono, S. S. and B. W. S. (2019). Wayang Beber Animation Media as An Effort for Preserving Wayang Tradition Based on Information and Technology. International Conference Computer Science and Engineering (IC2SE), Journal of Physics: Conference Series PAPER, 1-5. https://doi.org/10.1088/17426596/1339/1/012109

Buana, D. R. (2020). Analisis Perilaku Masyarakat Indonesia dalam Menghadapi Pandemi Virus Corona (Covid-19) dan Kiat Menjaga Kesejahteraan Jiwa. SALAM: Jurnal Sosial Dan Budaya Syar-I, 7(3), 217-226. https://doi.org/10.15408/sjsbs. v7i3.15082

Gilang, L., Sihombing, R. M., \& Sari, N. (2017). Kesesuaian Konteks Dan Ilustrasi Pada Buku Bergambar Untuk Mendidik Karakter Anak. Jurnal Pendidikan Karakter, VII(2), 158-169. https://doi.org/https://doi. org/10.21831/jpk.v7i2.15799

Hartiningsih, S. (2015). Revitalisasi Lagu Dola- nan Anak dalam Pembentukan Karakter Anak Usia Dini. Atavisme, 18(2), 247259. https://doi.org/10.24257/atavisme. v18i2.119.247-259

Heriwati, S. H., Prilosadoso, B. H., Pujiono, B., Suwondo, \& Panindias, A. N. (2019). 3D Puppets Animation for Encouraging Character Education and Culture Preservation in Surakarta. International Journal of Engineering and Advanced Technology, 9(1), 1551-1555. https://doi.org/10.35940/ ijeat.A1341.109119

Kristanto. (2011). Gambar Ilustrasi Buku Cerita Anak-Anak Sebagai Pelestarian dan Pengembangan Budaya di Era Globalisasi. Malih Peddas, 1(2), 61-72. https://doi. org/https://doi.org/10.26877/malihpeddas. v1i2.302

Maharsi, I. (2016). Ilustrasi. In ISI yogyakarta. ISI Yogyakarta. http://digilib.isi.ac.id/id/ eprint/1167

Maryaeni, M. (2009). Kajian Tembang Dolanan Dan Implikasinya Dalam Pendidikan Budi Pekerti Anak Bangsa Pada Pendidikan Dasar Dan Menengah. Jurnal Pendidikan Dan Pembelajaran Universitas Negeri Malang, 16(2), 186-193. http://journal. um.ac.id/index.php/pendidikan-dan-pembelajaran/article/view/2833

Olivia, R., Estoni, C., Firdausi, N. A., Susetya, B. A., \& Prilosadoso, B. H. (2019). Pelestarian Cerita Ramayana Melalui Media Wayang Limbah Kertas Untuk Siswa Sekolah Dasar di Sukoharjo. Seminar Nasional: Seni, Teknologi, Dan Masyarakat \#4 2019 ISI Surakarta, 2, 245-251. https://doi.org/DOI: 10.33153/semhas.v2i0.128

Pramana, C. (2020). Siapkah Dokter menghadapi Pandemi akibat Covid-19. 480(March), 0-6. https://doi.org/10.13140/ RG.2.2.35338.62402

Prasetyo, Y. A. (2014). Ilustrasi Buku Cerita Fabel Sebagai Media Pendidikan Karakter Anak. Arty: Journal of Visual Arts, 3(1), 5-8. https://journal.unnes.ac.id/sju/index. php/arty/article/view/4024 
Prilosadoso, B. H, Sutedjo, Agus., Soewasta, M. (2017). Media Pembelajaran Pemberdayaan Masyarakat Melalui Teknologi Cetak Saring Untuk Pembuatan Souvenir Sebagai Upaya Peningkatan Kunjungan Wisatawan di Desa Wisata Betisrejo, Sragen. Batoboh, 2(2), 99-108. https://doi. org/http://dx.doi.org/10.26887/bt.v2i2.353

Prilosadoso, B. H., Pujiono, B., \& Supeni, S. (2020). The Character of the Pacitan Wayang Beber Cartoon as a Cultural Preservation Effortfor Millennial's Generation. International Journal of Advanced Science and Technology, 29(4), 2517-2522. http:// sersc.org/journals/index.php/IJAST/article/ view/21090

Prilosadoso, H., \& B, Suyanto, Rosmiati, Ana., H. (2017). Identitas Visual Desa Wisata Batik Cokrokembang Melalui Environment Graphic Design Sebagai Pengembangan di Kabupaten Pacitan. Acintya Jurnal Penelitian Seni Budaya, 9(1), 17-22. https:// jurnal.isi-ska.ac.id/index.php/acintya/article/view/2120

Retnoningsih, D. A. (2019). Pembentukan Sikap Tata Krama Siswa Sekolah Dasar Melalui Revitalisasi Pembiasaan Tembang Dolanan. Lingua Rima: Jurnal Pendidikan Program Studi Bahasa Dan Sastra Indonesia, 8, 61-70. https://doi.org/http://dx.doi. org/10.31000/lgrm.v8i2.1790

Susilo, Y. (2018). Pembelajaran Tembang Dolanan Untuk Melestarikan Bahasa Ibu Mengandung Ajaran Budi Pekerti. Seminar Nasional Bahasa, Sastra Daerah, Dan Pembelajarannya (SN-BSDP) Program Studi Pendidikan Bahasa Dan Sastra Daerah FPBS - Universitas PGRI Semarang Di Semarang, JAwa Tengah 21 Februari 2018, 441-448. http://prosiding. upgris.ac.id/index.php/pbsd18/pbsd2018/ paper/view/2421
Sutanto. Jessica, P, Cok Gede, Tedjokoesoemo, P. E. D. (2017). Upcycle Limbah Kayu Palet Jati Belanda Menjadi Wadah Modular Serbaguna Untuk Anak-Anak (Studi Kasus: Kota Surabaya). IDIMENSI INTERIOR, 15(1), 26-34. https://doi. org/10.9744/interior.15.1.26-34

Sutedjo, Agus, Prilosadoso, B. H. (2016). Perancangan Desain Permainan Materi Pendidikan Anak Usia Dini Berbasis Wayang Beber. Acintya Jurnal Penelitian Seni Budaya, ISI Surakarta, 8(1), 17-24. https://doi.org/https://doi.org/10.33153/ acy.v8i1.1909

Wajdi, M. B. N., Iwan Kuswandi, Umar Al Faruq, Zulhijra, Z., Khairudin, K., \& Khoiriyah, K. (2020). Education Policy Overcome Coronavirus, A Study of Indonesians. EDUTEC : Journal of Education And Technology, 3(2), 96-106. https://doi. org/10.29062/edu.v3i2.42

Waluyo. (2018). Transidentalisme Seni dan Budaya : Kajian Apresiasi Kritis Estetika Islam. Jurnal Penelitian, 12(1), 65-84. https://doi.org/10.21043/jp.v12i1.4130

Yunita, L. S. (2014). Bentuk Dan Fungsi Simbolis Tembang Dolanan Jawa. Nosi, 2(5),472-478. http://scholar.googleusercontent.com/scholar?q=cache:I_-YJT-7iNEJ:scholar.google.com/+BENTUK+DAN+FUNGSI+SIMBOLIS+TEMBANG+DOLA$\mathrm{NAN}+J A W A \& h l=i d \&$ as_sdt $=0,5$

Yunus, N. R., \& Rezki, A. (2020). Kebijakan Pemberlakuan Lock Down Sebagai Antisipasi Penyebaran Corona Virus Covid-19. SALAM: Jurnal Sosial Dan Budaya Syar-I, 7(3). https://doi.org/10.15408/sjsbs. v7i3.15083

Zahrotunnimah, Z. (2020). Langkah Taktis Pemerintah Daerah Dalam Pencegahan Penyebaran Virus Corona Covid-19 di Indonesia. SALAM: Jurnal Sosial Dan Budaya Syar-I, 7(3). https://doi.org/10.15408/ sjsbs.v7i3.15103 